\title{
Recurrent Endometrial Clear Cell Adenocarcinoma
}

National Cancer Institute

\section{Source}

National Cancer Institute. Recurrent Endometrial Clear Cell Adenocarcinoma. NCl

Thesaurus. Code C155816.

The reemergence of endometrial clear cell adenocarcinoma after a period of remission. 